\title{
Targeting non-viral vectors to tumor cells and the tumor microenvironment
}

\author{
Vera Moura ${ }^{1,2}$, Manuela Lacerda ${ }^{3}$, Paulo Figueiredo ${ }^{3}, \mathrm{M} \mathrm{L} \mathrm{Corvo}^{4}, \mathrm{M}$ Eugénia M Cruz ${ }^{4}, \mathrm{M}$ Conceição P de Lima ${ }^{2,5}$, \\ Sérgio Simões ${ }^{1,2}$, João N Moreira ${ }^{1,2^{*}}$ \\ From 16th International Charles Heidelberger Symposium on Cancer Research \\ Coimbra, Portugal. 26-28 September 2010
}

Targeted therapy towards tumor cells has been regarded as a promising strategy, since it offers the possibility of directing and concentrating the therapeutic agent only at the desired target site, increasing therapeutic efficacy through increased tumor cell death and decreased incidence of side effects in healthy tissues. Nonetheless, choosing only one cellular target within the tumor microenvironment is an approach with low probabilities to succeed. In this respect, we aim at designing a nonviral vector that targets, simultaneously, tumor cells and endothelial cells from tumor blood vessels. It is hypothesized that such nanoparticle, with this dual targeting ability, will present an active tumor accumulation. Specific intracellular release of the encapsulated payload will strongly contribute to improve the therapeutic outcome.

Our results show a substantial increase in the levels of association for ligand-targeted nanoparticles, on a ligand- and cell-specific manner, both in vitro and ex vivo (in breast tumor cells removed from patients, after mastectomy or tumorectomy). Cytotoxicity studies show that targeted nanoparticles containing doxorubicin are more cytotoxic than the non-targeted formulation (4 to 180-fold), against tumor and endothelial cells, indicating that internalization of the former is contributing to a more efficient delivery of the payload to the target cells. Experiments with tumor-bearing mice report a higher tumor accumulation of the radiolabeled targeted nanoparticle over the non-targeted counterpart. Overall, these results represent a novel and a valuable contribution for delivery strategies targeting tumor cells and the tumor microenvironment.

* Correspondence: jmoreira@ff.uc.pt

${ }^{1}$ Faculty of Pharmacy, University of Coimbra, Coimbra, Portugal

Full list of author information is available at the end of the article
Author details

${ }^{1}$ Faculty of Pharmacy, University of Coimbra, Coimbra, Portugal. ${ }^{2}$ Center for Neuroscience and Cell Biology, University of Coimbra, Coimbra, Portugal.

${ }^{3}$ Portuguese Institute of Oncology Francisco Gentil, Coimbra, Portugal. ${ }^{4}$ Research Institute for Medicines and Pharmaceutical Sciences, Faculty of Pharmacy, University of Lisbon, Lisbon, Portugal. ${ }^{5}$ Department of Life Sciences, University of Coimbra, Coimbra, Portugal.

Published: 24 September 2010

\section{doi:}

Cite this article as: Moura et al:: Targeting non-viral vectors to tumor cells and the tumor microenvironment. BMC Proceedings 2010 4(Suppl 2): O26.
Submit your next manuscript to BioMed Central and take full advantage of:

- Convenient online submission

- Thorough peer review

- No space constraints or color figure charges

- Immediate publication on acceptance

- Inclusion in PubMed, CAS, Scopus and Google Scholar

- Research which is freely available for redistribution

Submit your manuscript at www.biomedcentral.com/submit
C Biomed Central 